\title{
Estimating cassava yield in future IPCC climate scenarios for the Rio Grande do Sul State, Brazil
}

\author{
Luana Fernandes Tironi ${ }^{1}$ Nereu Augusto Streck $^{1 *}$ Amanda Thirza Lima Santos ${ }^{1}$ \\ Charles Patrick de Oliveira de Freitas ${ }^{1}$ Lilian Osmari Uhlmann ${ }^{1}$ \\ Wolnei Castro de Oliveira Júnior ${ }^{1}$ Simone Erotildes Teleginski Ferraz ${ }^{2}$
}

\footnotetext{
${ }^{1}$ Departamento de Fitotecnia, Universidade Federal de Santa Maria (UFSM), 97105-900, Santa Maria, RS, Brasil. E-mail: nstreck2@yahoo.com.br "Corresponding author.

${ }^{2}$ Departamento de Física, Universidade Federal de Santa Maria (UFSM), Santa Maria, RS, Brasil.
}

\begin{abstract}
The objective of this study was to simulate the yield of two cassava cultivars in two IPCC future climate scenarios, the SRESA1B (Cmip3) and the RCP4.5 (Cmip5), for the state of Rio Grande do Sul, Brazil. The Simanihot model, with the Thornthwaite and Mather water balance sub-model, and the SRES-A1B (Cmip3 - Third Coupled Model Intercomparison Project) and RCP4.5 (Cmip5 - Fifth Coupled Model Intercomparison Project) scenarios of the Fourth and Fifth IPCC Assessment Report, respectively, was used. Cassava cultivars used in this study were 'Fepagro - RS13' (forrage) and 'Estrangeira' (human consumption). In both cultivars, there was an increase in tuberous roots yield in future climate scenarios. The cultivar for human consumption benefits more roots yield in the scenario with higher $\mathrm{CO}{ }_{2}(\mathrm{Cmip} 3$ scenario); whereas, the forage cultivar benefits more the Cmip5 scenario. Among the three future periods (2010-2039, 2040-2069 e 20702099), changes in tuberous roots yield are more evident in the end of the century period (2070-2099) and for early planting dates (01 September and 01 October). The northeastern region of the state has the greatest changes in tuberous roots yield in future climates, because this is the coldest region, with winter minimum temperature during between 6 and $8^{\circ} \mathrm{C}$.
\end{abstract}

Key words: Simanihot, agricultural modeling, elevated temperature, elevated $\mathrm{CO}_{2}$.

Produtividade simulada de mandioca em cenários climáticos futuros do IPCC para o Rio Grande do Sul, Brasil

RESUMO: O objetivo deste trabalho foi simular a produtividade de duas cultivares de mandioca em dois cenários climáticos futuros do IPCC, o SRES-A1B (Cmip3) e o RCP4.5 (Cmip5), para o Rio Grande do Sul. Foi utilizado o modelo Simanihot, com o submodelo de balanço hídrico do solo diário sequencial de Thornthwaite e Mather, e os cenários SRES-A1B (Cmip3 - 3o Projeto de Intercomparação de modelos globais) e o RCP4.5 (Cmip5 - 5o Projeto de Intercomparação de modelos globais) do 4o e 5o relatório do IPCC, respectivamente, regionalizados por downscaling dinâmico com modelo RegCM3 e RegCM4 (Modelo Climático Regional), respectivamente. As cultivares utilizadas no estudo foram a 'Fepagro - RS13' (uso forrageira) e 'Estrangeira' (uso para mesa). Em ambas há aumento na produtividade de raízes em cenários climáticos futuros. A cultivar de mesa se beneficia mais na produtividade de raízes no cenário com maior concentração de CO (cenário Cmip3), enquanto a cultivar forrageira, se beneficia mais no cenário Cmip5. Nos três períodos futuros (2010-2039, 2040-2069 e 2070-2099), as mudanças na produtividade são sempre mais expressivas no último período (2070-2099) e nas primeiras datas de plantio (01/09 e 01/10). A região do Rio Grande do Sul com maiores mudanças na produtividade é a nordeste, a qual, no clima atual é a mais fria do Estado, com temperatura mínima do ar no inverno entre 6 e $8^{\circ} \mathrm{C}$.

Palavras-chave: Simanihot, modelagem agrícola, aumento de temperatura, aumento de $\mathrm{CO}_{2}$.

\section{INTRODUCTION}

The Intergovernmental Panel on Climate Change (IPCC, 2007, 2013) has reported impacts of the greenhouse effect on meteorological variables such as air temperature, solar radiation and precipitation, which in turn directly influence the growth and developmental processes of agricultural crops. One of the most significant crops for food security and the main food source of several countries in Africa and Asia is cassava (Manihot esculenta Crantz L.). In the Rio Grande do Sul state, cassava plays a key role in family farming. 
As a result of its social significance in the developing nations, field and greenhouse experimental research is gaining momentum (IMAI et al., 1984; ROSENTHAL et al., 2012) and increasing in number (CHINVANNO, 2004; LIU et al., 2008; LOBELL et al., 2008; SCHLENKER \& LOBELL, 2010). However, studies focused on assessing the impact of climate scenarios in the future on cassava productivity in Rio Grande do Sul are not available.

Future climate scenarios of the IPCC include the SRES-A1B scenario (Cmip3 - $3^{\text {rd }}$ Intercomparison Project global models), an intermediate scenario between the least advantageous scenarios (A1, A2) and the most beneficial ones (B1, B2) of the $4^{\text {th }}$ IPCC Assessment Report, and the RCP4.5 scenario (Cmip5 - $5^{\text {th }}$ Intercomparison Project global models), which is also an intermediate scenario of the $5^{\text {th }}$ IPCC Assessment Report. These two scenarios showed variations in the trends of the meteorological variables. In the SRES-A1B (Cmip3), the $\mathrm{CO}_{2}$ concentration begins with 300ppm in 1960 and reaches $710 \mathrm{ppm}$ by 2100 (IPCC, 2007), while in the $\mathrm{RCP} 4.5$ scenario (Cmip5) the $\mathrm{CO}_{2}$ concentration is around $300 \mathrm{ppm}$ in 1960 and goes up to $538 \mathrm{ppm}$ by 2100 (IPCC, 2013). The surface temperature is projected to increase during the $21^{\text {st }}$ century in both scenarios and rainfall changes will vary depending upon location on the planet (IPCC, 2007, 2013). To study the response of the cassava cultivation in these future scenarios, dynamic process-based models, such as the Simanihot (TIRONI, 2016), are suitable tools as they describe the processes that affect the root growth and take into account the effect of $\mathrm{CO}_{2}$ fertilization and soil water balance.

The objective of this study was to simulate the yield of two cassava cultivars in two future climate scenarios of the IPCC, the SRES-A1B (Cmip3) and RCP4.5 (Cmip5) in the Rio Grande do Sul state, Brazil.

\section{MATERIALS AND METHODS}

The Simanihot, version $1.2<$ www.ufsm. br/simanihot $>$, was the cassava model used in this study. It is a dynamic process-based model which calculates the crop growth and development in a daily step, taking into account the effects of water stress and the fertilizing effect of $\mathrm{CO}_{2}$ on several growth and developmental processes, including tuberous roots (TIRONI, 2016). The Simanihot model was forced by the SRES-A1B scenario (Cmip3) of the 4th IPCC Assessment Report (IPCC, 2007) and the RCP4.5 scenario (Cmip5) of the $5^{\text {th }}$ IPCC Assessment Report (IPCC, 2013). The boundary conditions and $\mathrm{CO}_{2}$ were from the ECHAM5 global model (ROECKNER, 2005) for the Cmip3 and HadGEM2-ES global model (JONES et al., 2011) for Cmip5. The scenarios were regionalized by dynamic downscaling (HOSTETLER et al., 2011) with the RegCM3 model (Regional Climate Model version 3) for the Cmip3, and with the RegCM4 model (Regional Climate Model version 4) for the Cmip5. The downscaling was for a total of 37 points across the state.

In addition to a previous validation of the Simanihot model by GABRIEL et al. (2014), we also compared observed tuberous roots yield data from field experiments at four locations in the RS State (Santa Maria, Vera Cruz, Rio Pardo and Glorinha) during 12 growing seasons (Figure 1), for two cultivars ('Fepagro-RS13' and 'Estrangeira') in different planting dates, harvesting dates, and plant densities. Yield was calculated with the Simanihot in terms of tons/ha of fresh weight using as the input data the actual meteorological variables recorded at the weather stations of the Instituto Nacional de Meteorologia (INMET) and the meteorological variables of the future scenarios.

The 120-year period for each climate scenario was divided into the baseline period (19802009) and three future periods: 2010-2039, 20402069 and 2070-2099. Tuberous roots yield (ton/ ha of fresh weight) for each period was simulated by running the Simanihot model in both scenarios (Cmip3 and Cmip5) for two cultivars, 'FepagroRS13' (grown for forage in the RS) and 'Estrangeira' (one of the most cultivated in the RS and well accepted for consumption) (CARDOSO et al., 2004), in four planting dates $(\mathrm{dd} / \mathrm{mm}): 01 / 09,01 / 10,01 / 11$ and $01 / 12$. Harvest date was set on 15 June. The Simanihot model was run without water limitation (potential condition) and with the soil water-balance model activated (rain fed condition) using the daily water balance according to THORTHWAITE \& MATHER (1955). The potential evapotranspiration (ETo) was calculated using the Penman-Monteith method. The Simanihot software contains a database of soils of the Rio Grande do Sul and the physical properties such as the water content of the soils were calculated for different water tensions, essential for calculating the soil water balance, through a pedotransfer function used in the Hydrus model (SIMUNEK et al., 2013). 


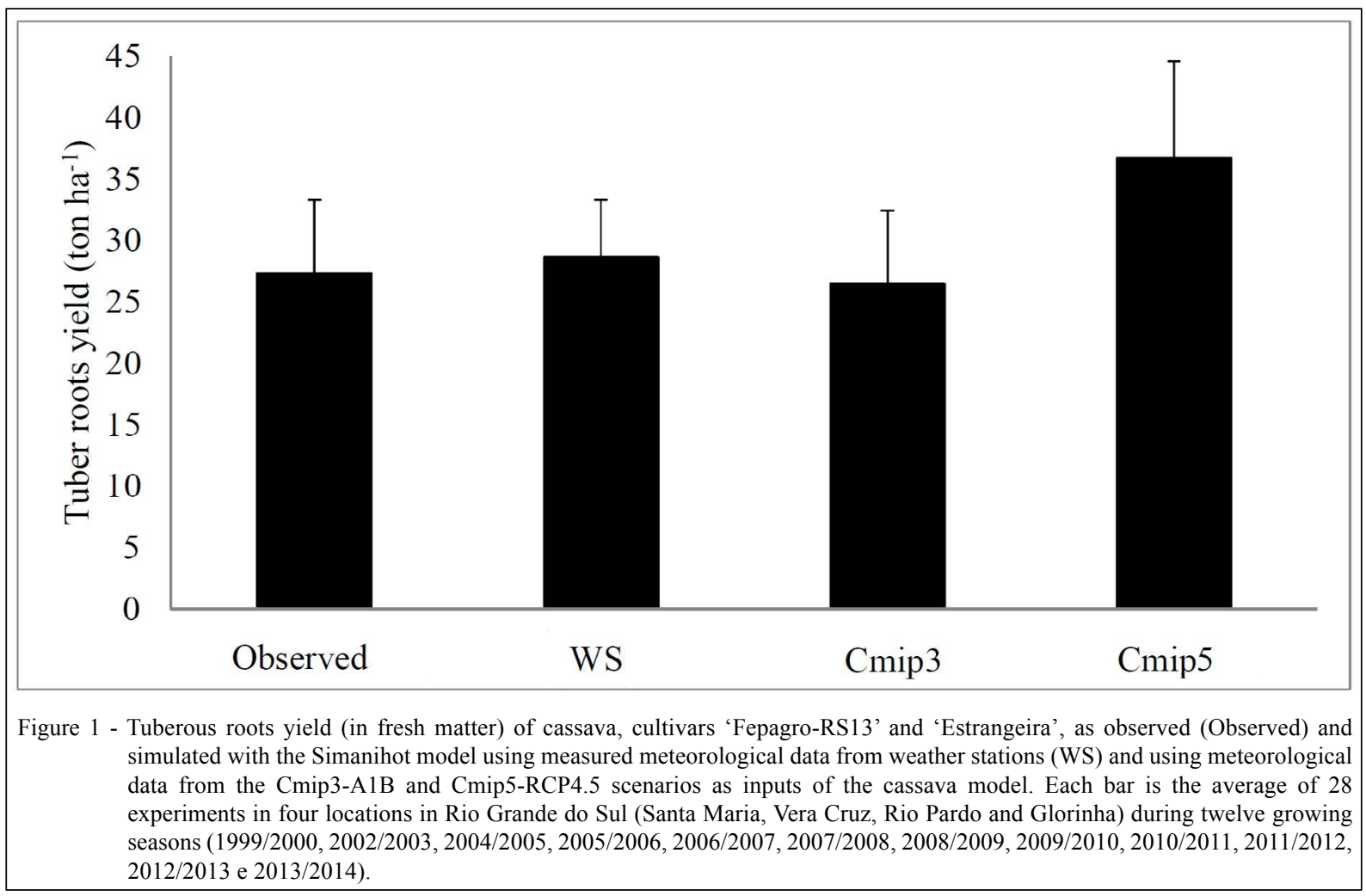

\section{RESULTS AND DISCUSSION}

The tuberous roots yield averaged around 8 tons/ha more in the Cmip5 than in the Cmip3 scenario (Figure 1), because of greater solar radiation in the Cmip5 scenario (annual average around $23 \mathrm{MJ}$ $\mathrm{m}^{-2}$ day $^{-1}$ in the Cmip5 compared to $15 \mathrm{MJ} \mathrm{m}^{-2}$ day $^{-1}$, Figure 2A), lower precipitation (accumulated rainfall achieving nearly $5000 \mathrm{~mm}$ per year in the central region of the state in the Cmip3 scenario compared to $1500 \mathrm{~mm}$ in the Cmip5 scenario), and a higher inter annual variability of precipitation in the Cmip3 scenario (Figure 2B). Minimum air temperature is similar in both future scenarios up to around 2060, and from then on the increase in minimum air temperature is greater in Cmip3 (Figure 2C). The maximum temperature is higher in Cmip5 except in the eastern part of the state, and overall, the Cmip3 scenario experiences had lower thermal amplitude than does the Cmip5 (Figure 2D).

The tuberous roots yield for the baseline period was higher in the Cmip5 scenario for both cultivars, achieving values greater than 30 tons ha-1 for nearly the entire State in the 01/09 and 01/10 planting dates (data not shown). Yields in the baseline period was greater in the northwest part of the state, where air temperature and solar radiation are higher. This is in agreement with currently climatology, where temperature and solar radiation in this region is around $25^{\circ} \mathrm{C}$ and $26 \mathrm{MJ} \mathrm{m}^{-2}$ day $^{-1}$ during the summer compared with the northeast region, where they are around $19-20^{\circ} \mathrm{C}$ and $21-22 \mathrm{MJ} \mathrm{m}^{-2}$ day $^{-1}$ (MATZENAUER et al., 2011).

The 'Fepagro-RS13' cultivar in the Cmip3 scenario, for the three future periods (2010-2039, 2040-2069 and 2070-2099), showed higher tuberous roots yield changes in the earlier planting dates $(01 / 09$ and $01 / 10)$ and in the end of the century (2070-2099). The northeast part of the state, which is normally less productive due to low winter temperatures $\left(6\right.$ to $\left.8^{\circ} \mathrm{C}\right)$ (MATZENAUER et al., 2011), showed the highest increase in cassava yield (Figure 3) benefiting more from the rise in air temperature and $\mathrm{CO}_{2}$ concentration. The northwest region of the state revealed the least changes in yield in all the planting dates and during all the three future periods (Figure 3). For the cultivar 'Estrangeira', in this scenario, yield increase was also during the last future period (2070-2099), with a rise of up to 30 tons/ha in the earlier planting dates $(01 / 09$ and $01 / 10$ ) in almost every state (Figure 4). 

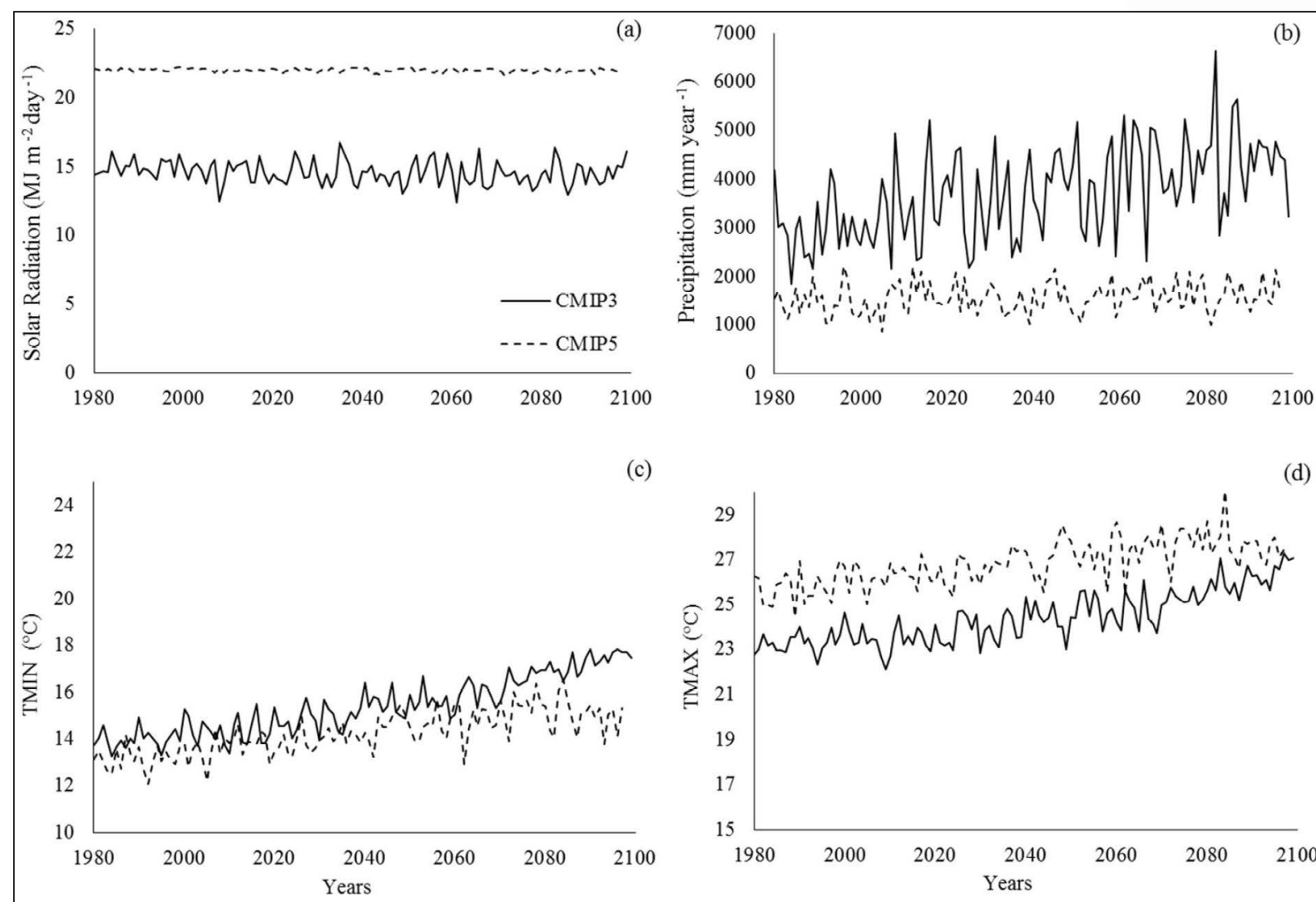

Figure 2 - Average annual solar radiation (a), total annual precipitation (b), (c) annual average minimum air temperature (c), and average annual maximum air temperature (d) in the Cmip3 (solid line) and in the Cmip5 (dashed line) scenarios in the central region of Rio Grande do Sul State during the 1980-2099 period.

The tuberous roots yield changes for the cultivar 'Fepagro-RS13' was higher in the Cmip5 scenario (Figure 5) and lower for the cultivar 'Estrangeira' (Figure 6) during the three future periods (Figures 3 and 4). Elevated temperatures in both scenarios were advantageous to the crop because high temperatures are associated with higher rates of growth and photosynthesis in cassava (EL-SHARKAWY et al., 1992); however, differences in $\mathrm{CO}_{2}$ concentration between these two scenarios was the main reason for the difference in the results among cultivars. The $\mathrm{CO}_{2}$ enrichment (Cmip3 scenario) was more advantageous for the cultivar 'Estrangeira' than for the forage cultivar 'Fepagro - RS 13' because in this scenario the forage cultivar increased above ground growth, which resulted in the reduced growth of the tuberous roots. Precipitation did not appear to be a limiting factor for tuberous root growth because the yields simulated without (data not shown) and with the soil water balance turned on was similar, implying that seasonal water supply was enough.

Previous numerical studies indicated decrease or almost no changes in the cassava yield in future climate scenarios (LOBELL et al., 2008; LIU et al., 2008; SCHLENKER \& LOBELL, 2010), varying from -3.7 to $17.5 \%$ over the African continent (JARVIS et al., 2012), and increased productivity during the wet seasons in Thailand (CHINVANNO, 2004). Most of these studies were in the tropics, mainly Africa and Thailand, and only a few took into account the influence of $\mathrm{CO}_{2}$ on cassava yield (CHINVANNO, 2004; LIU et al., 2008). Results of the present study agree with the results from $\mathrm{CO}_{2}$ field enrichment experiments with cassava (IMAI et al., 1984; ROSENTHAL et al., 2012), that cassava can benefit from raising temperatures in the subtropics, which are currently marginal its growth, because in the future the risk for low air temperatures in these regions is lower (ASSAD \& PINTO, 2008). 


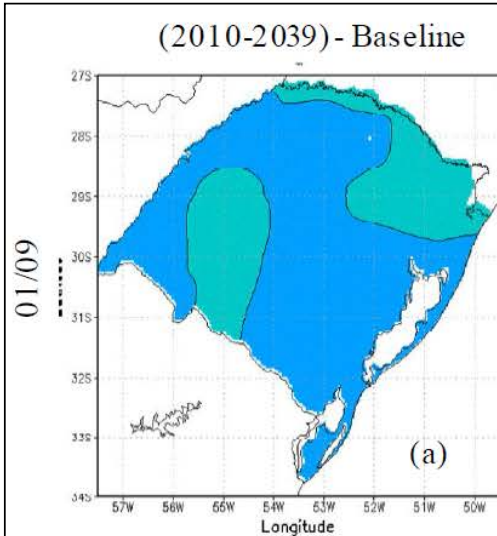

(2040-2069) - Baseline
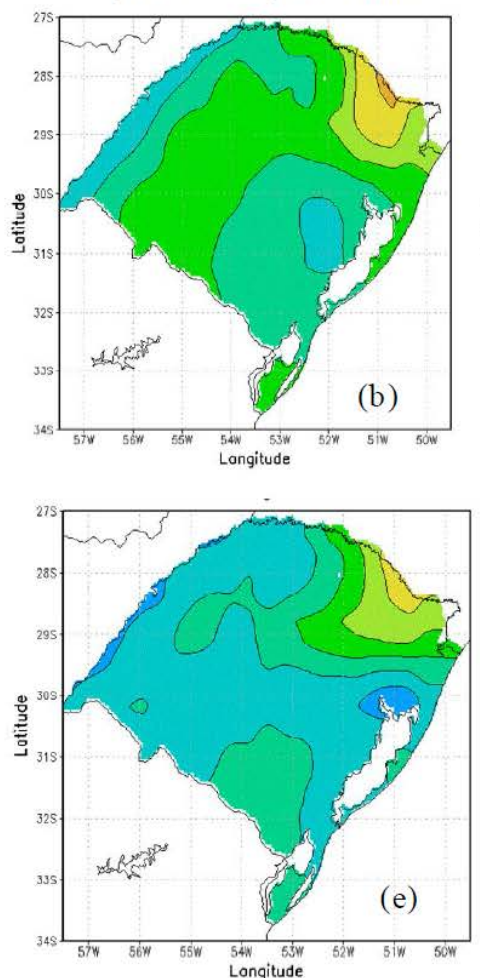

(e)

(d)
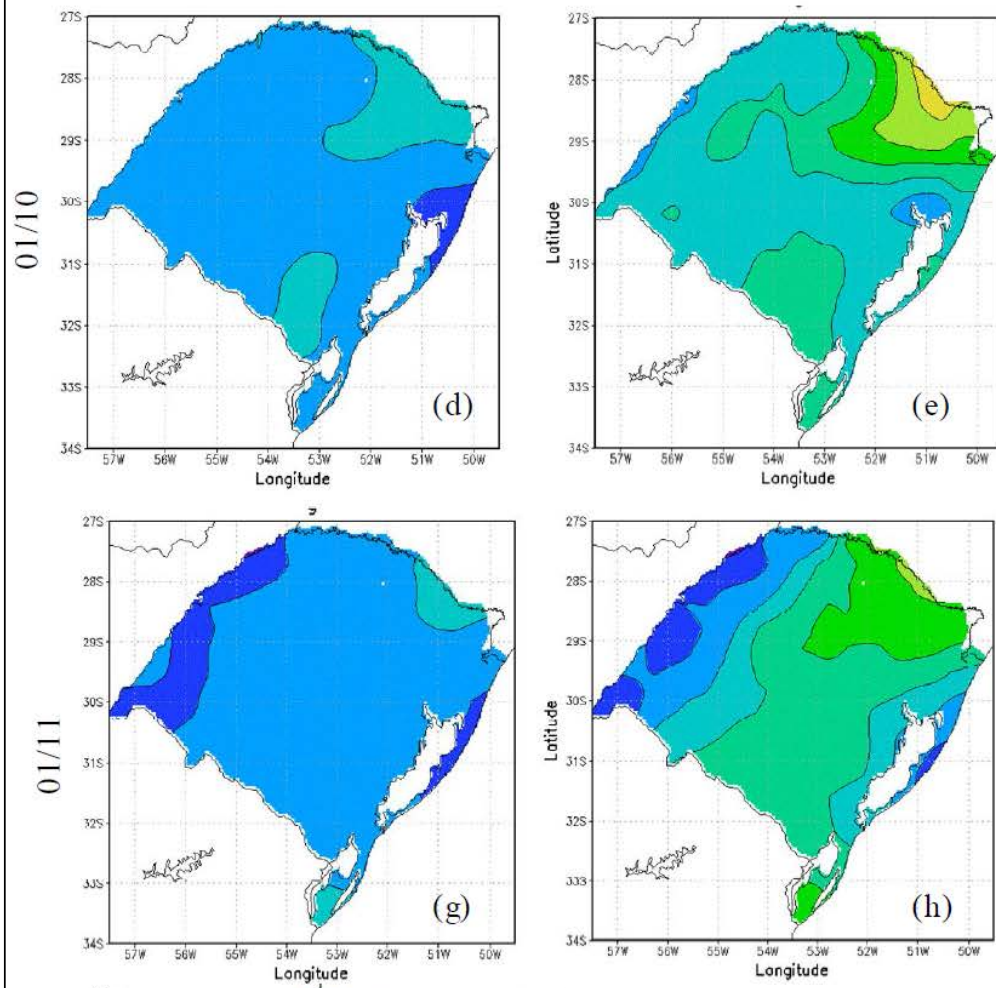

(h)

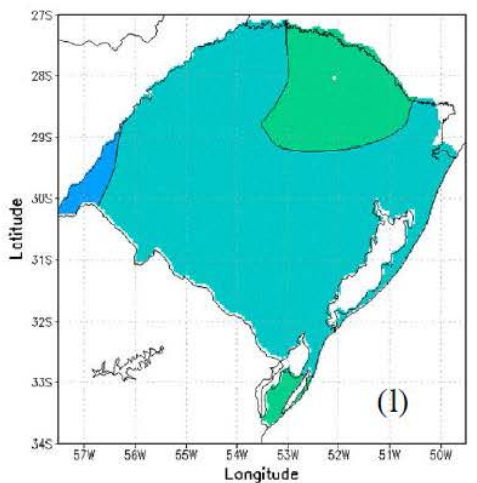

(2070-2099) - Baseline

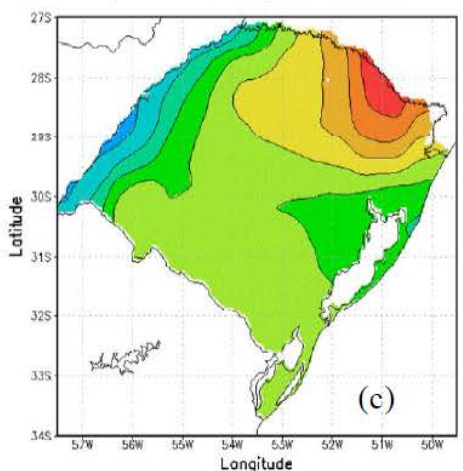

(c)
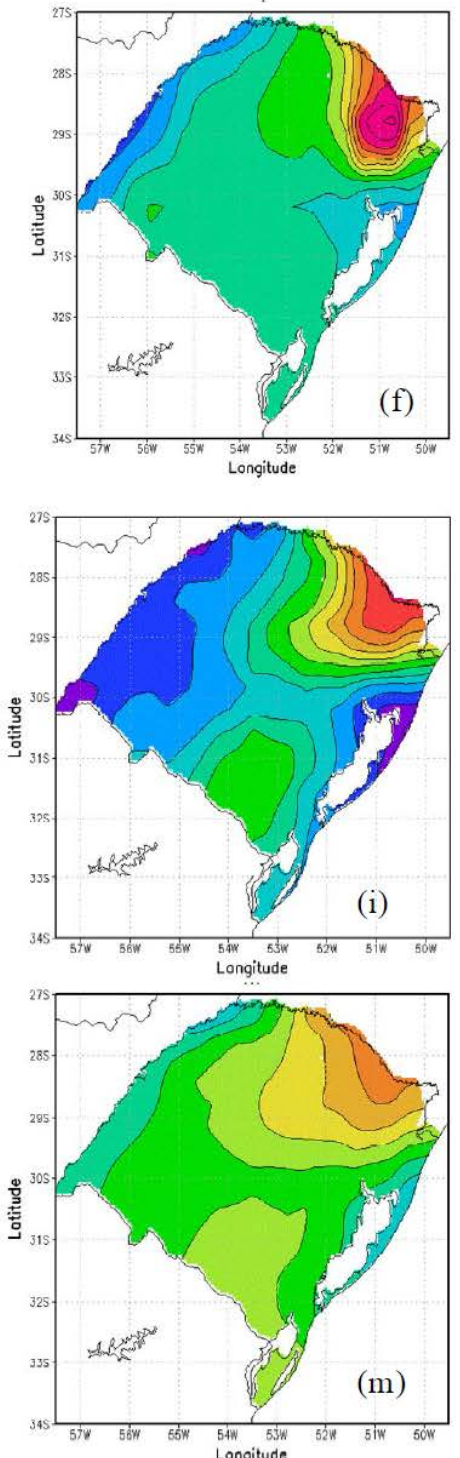

Figure 3 - Change in yield of tuberous roots fresh matter (ton ha ${ }^{-1}$ ) of the cassava cultivar 'Fepagro-RS' 13 in Rio Grande do Sul State, Brazil, as simulated with the Simanihot model for three future periods of the Cmip3-A1B scenario (2010-2039, 2040-2069, 2070-2099) in four planting dates (dd/mm): 01/09 (a, b, c), 1/10 (d, e, f), 01/11 (g, h, i) and $01 / 12(\mathrm{j}, 1 \mathrm{~m})$. 

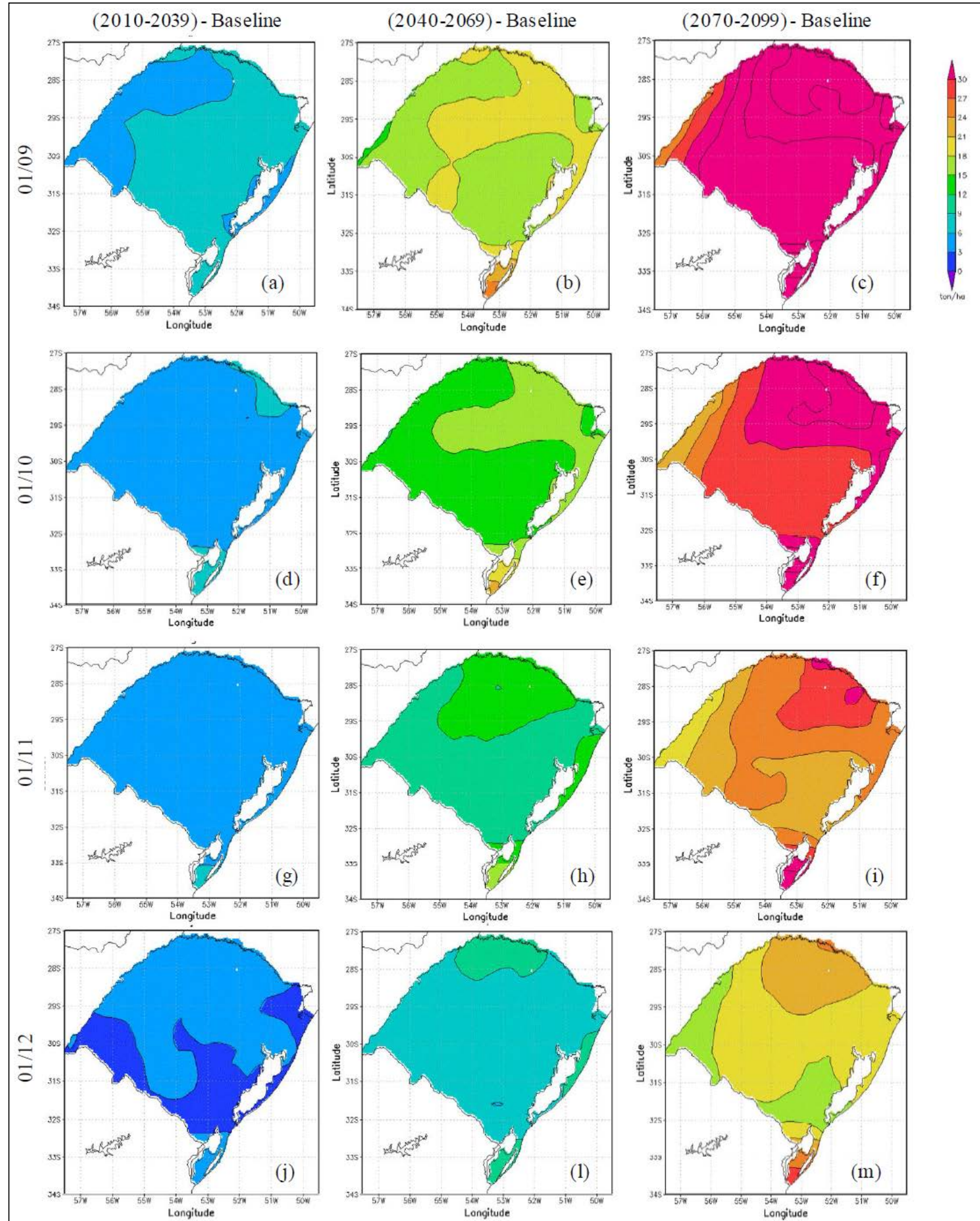

Figure 4 - Change in yield of tuberous roots fresh matter (ton ha ${ }^{-1}$ ) of the cassava cultivar 'Estrangeira' in Rio Grande do Sul State, Brazil, as simulated with Simanihot model for three future periods of the Cmip3-A1B scenario (2010-2039, 2040-2069, 2070-2099) in four planting dates (dd/mm): 01/09 (a, b, c), 1/10 (d, e, f), 01/11 (g, h, i) and 01/12 (j, 1, m). 


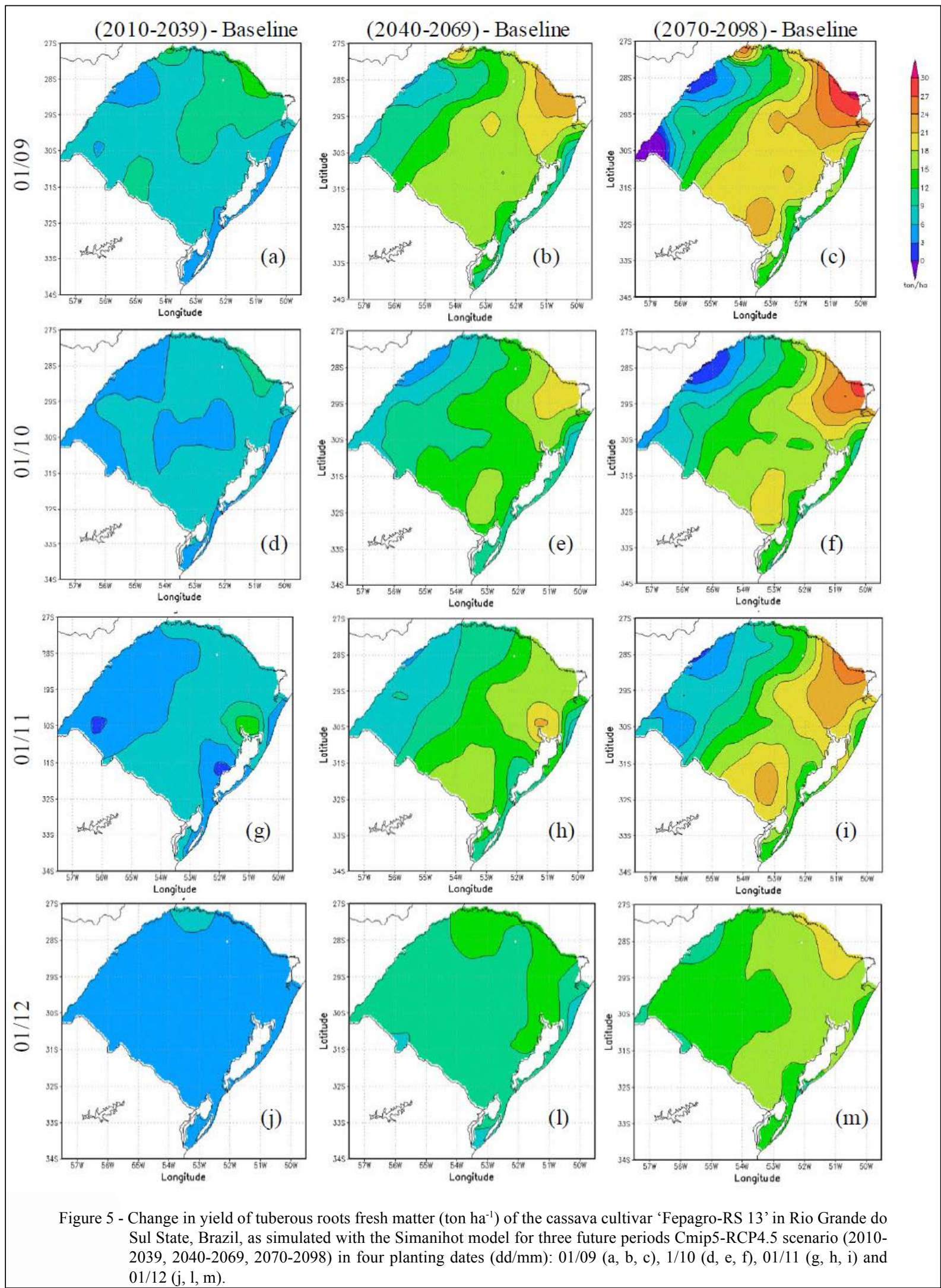

Ciência Rural, v.47, n.2, 2017. 

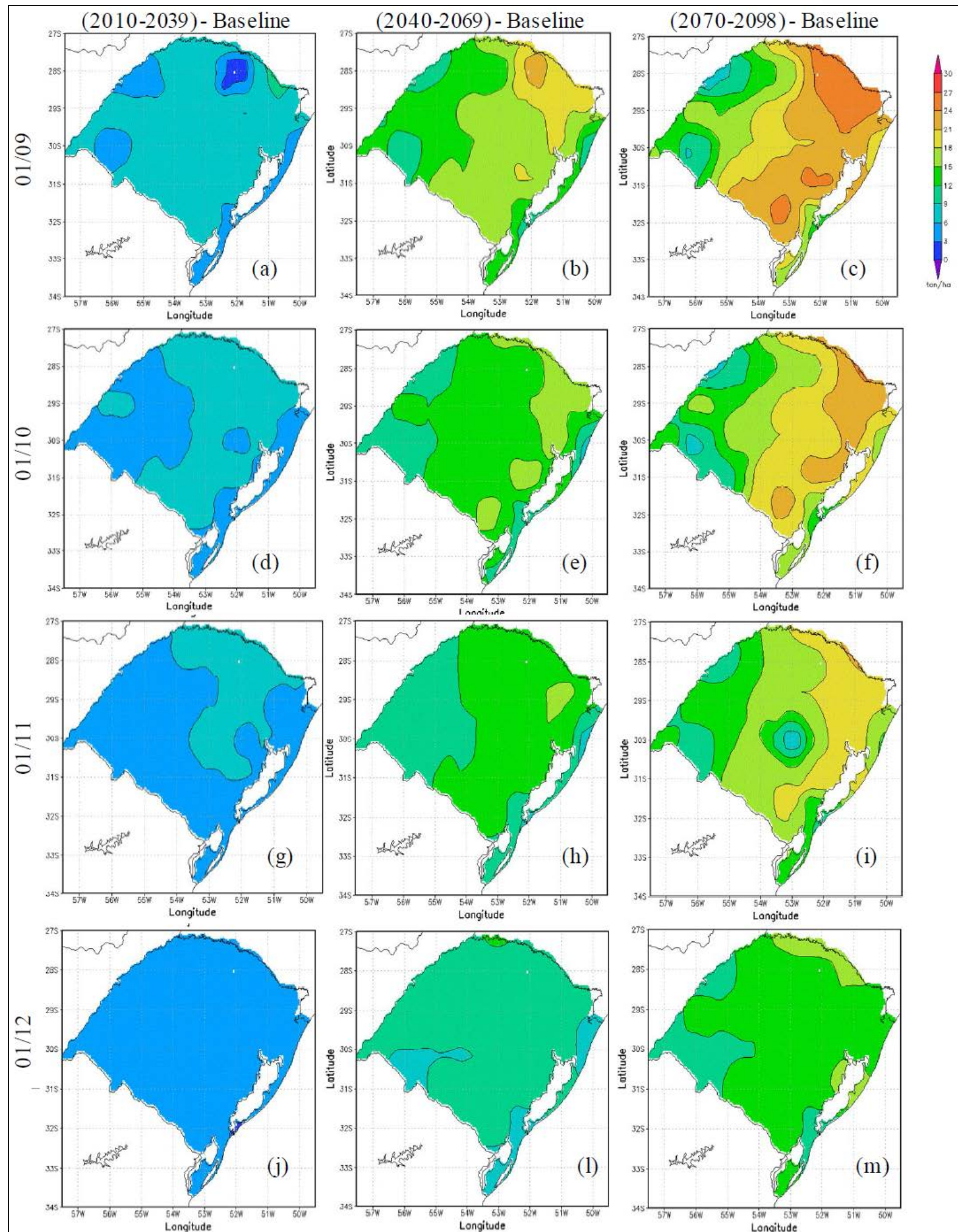

Figure 6 - Change in yield of tuberous roots fresh matter (ton ha-1) of the cassava cultivar 'Estrangeira' in Rio Grande do Sul State, Brazil, as simulated with the Simanihot model for three future periods of the Cmip5-RCP4.5 scenario (20102039, 2040-2069, 2070-2098) and four planting dates (dd/mm): 01/09 (a, b, c), 1/10 (d, e, f), 01/11 (g, h, i) and $01 / 12(\mathrm{j}, 1, \mathrm{~m})$. 


\section{CONCLUSION}

Both cassava cultivars (forage and for human consumption) reveal higher tuberous root yield in future climate scenarios. However, while the cultivar for human consumption benefits more in the scenario with the highest $\mathrm{CO}_{2}$ concentration (Cmip3 scenario), the forage cultivar appears to benefit more in the Cmip5 scenario. The Cmip3 scenario, with its high $\mathrm{CO}_{2}$ concentration, appears to support increased shoot growth in the forage cultivar. Among the three future periods analyzed, tuberous roots yield changes are higher during the end of the century period (2070$2099)$ and in the early planting dates (01/09 and 01/10). The Northeastern region of the state has the greatest changes in tuberous roots yield in future climates, because this is the current coldest region, with winter minimum temperature during between 6 and $8^{\circ} \mathrm{C}$.

\section{ACKNOWLEDGEMENTS}

To Conselho Nacional de Desenvolvimento Cientifico e Tecnológico (CNPq) for scholarships (Proc. N 140342/2013-3).

\section{REFERENCES}

ASSAD, E.D.; PINTO, H.S. Aquecimento global e a nova geografia da produção agrícola no Brasil. São Paulo: Embrapa, 2008. 84p. Available from: <http://mudancasclimaticas.cptec. inpe.br/ rmclima/pdfs/destaques/CLIMA_E_AGRICULTURA_ BRASIL 300908 FINAL.pdf>. Accessed: Sept. 27, 2016

CARDOSO, E.T. et al. Stability and adaptability in root yield of cassava genotypes at two regions of Rio Grande do Sul state. Revista de Ciências Agroveterinárias, v.3, p.25-30, 2004. Available from: $<$ http://revistas.udesc.br/index.php/agroveterinaria/article/ viewFile/5475/3674>. Accessed: Sept. 27, 2016.

CHINVANNO, S. Building capacity of mekong river countries to assess impacts from climate change - Case Study Approach on Assessment of Community Vulnerability and Adaptation to Impact of Climate Change on Water Resources and Food Production. Final Report for APN CAPaBLE Project, 2004. Available from: $<$ http://cc.start.or.th/climateChange/Document/Doc eng 3.pdf $>$. Accessed: Jun. 05, 2014

EL-SHARKAWY, M.A. et al. Potential photosynthesis of cassava as affected by growth conditions. Crop Science, v.32, p.13361342, 1992. Available from: <https://dl.sciencesocieties.org/ publications/cs/abstracts/32/6/CS0320061336>. Accessed: Sept. 27, 2016. doi: 10.2135/cropsci1992.0011183X003200060006x.

GABRIEL, L.F. et al. Simulating cassava growth and yield under potential conditions in Southern Brazil. Agronomy Journal, v.106, p.1119-1137, 2014. Available from: <https://dl.sciencesocieties. org/publications/aj/abstracts/106/4/1119? access $=0 \&$ view $=$ pdf $>$. Accessed: Sept. 27, 2016. doi: 10.2134/agronj2013.0187.

HOSTETLER, S.W. et al. Dynamically downscaled climate simulations over North America: Methods, evaluation, and supporting documentation for users. Virginia: U.S. Geological Survey Open-File Report 2011-1238, 2011. 64p.

IMAI, K. et al. Elevated atmospheric partial pressure of carbon dioxide and dry matter production of cassava (Manihot esculenta Crantz). Japan Journal Crop Science, v.53, p.479485, 1984. Available from: <https://www.jstage.jst.go.jp/article/ jcs1927/53/4/53_4_479/_pdf>. Accessed: Sept. 27, 2016

IPCC. Climate change 2007: the physical science basis. Contribution of Working Group I to the Fourth Assessment Report of the Intergovernmental Panel on Climate Change. Cambridge: Cambridge University, 2007. 996p. Available from: <https:// www.ipcc.ch/publications_and_data/publications_ipcc_fourth assessment report wg1 report the physical_science basis.htm>. Accessed: Sept. 27, 2016.

IPCC. Climate change 2013: the physical science basis. Contribution of Working Group I to the Fifth Assessment Report of the Intergovernmental Panel on Climate Change - Summary for policy makers. Cambridge and New York: Cambridge University, 2013. 33p. Available from: $<$ https://www.ipcc.ch/pdf/assessmentreport/ar5/wg1/WGIAR5_SPM_brochure_en.pdf $>$. Accessed: Sept. 27, 2016

JONES, C.D. et al. The HadGEM2-ES implementation of CMIP5 centennial simulations. Geoscientific Model Development, v.4, p.543-570, 2011. Available from: <http://www.geosci-model-dev. net/4/543/2011/gmd-4-543-2011.pdf >. Accessed: Sept. 27, 2016. doi: 10.5194/gmd-4-543-2011.

LIU, J. et al. A spatially explicit assessment of current and future hotspots of hunger in sub-Saharan Africa in the context of global change. Global and Planetary Change, v.64, p.222-235, 2008. Available from: $<$ http://www.sciencedirect.com/science/article/pii/ S092181810800132X>. Accessed: Sept. 27, 2016. doi: 10.1016/j. gloplacha.2008.09.007.

LOBELL, D.B. et al. Prioritizing climate change adaptation needs for food security in 2030 Science, v.319, p.607-610, 2008. Available from: <https://web.stanford.edu/ mburke/papers/ Lobell_et_al_Science_2008.pdf $>$. Accessed: Sept. 27, 2016. doi: $10.1126 /$ science. 1152339

MATTHEWS, R.B.; HUNT, L.A. GUMCAS: a model describing the growth of cassava (Manihot esculenta L. Crantz). Field Crops Research, v.36, p.69-84, 1994. Available from: <http:// www.sciencedirect.com/science/article/pii/037842909490054X>. Accessed: Sept. 27, 2016. doi: 10.1016/0378-4290(94)90054-X.

MATZENAUER, R.; RADIN, B.; ALMEIDA, I.R.de. Atlas climático do Rio Grande do Sul. Fepagro, Porto Alegre. 2011. Available from: <http://www.cemet.rs.gov.br/area/7/Atlas Clim\%C3\%A1tico>. Accessed: Sept. 27, 2016.

ROECKNER, E. IPCC DDC AR4 ECHAM5/MPI-OM SRESA1B run1. World Data Center for Climate. CERA-DB "EH5_MPI OM_SRESA1B_1"http://cera-www.dkrz.de/WDCC/ui/Compact. jsp?acronym=EH5_MPI_OM_SRESA1B_1, 2005.

ROSENTHAL, D.M. et al. Cassava about-FACE:Greater than expected yield stimulation of cassava (Manihot esculenta) by future $\mathrm{CO}_{2}$ levels. Global Change Biology, v.18, p.2661-2675, 2012. Available from: $<$ http://onlinelibrary.wiley.com/doi/10.1111/ j.1365-2486.2012.02726.x/abstract>. Accessed: Sept. 27, 2016. doi: $10.1111 / \mathrm{j} .1365-2486.2012 .02726 . x$. 
SCHLENKER, W.; LOBELL, D.B. Robust negative impacts of climate change on African agriculture. Environmental Research Letters, v.5, 014010 (8p), 2010. Available from: <http:// iopscience.iop.org/article/10.1088/1748-9326/5/1/014010/ pdf $>$. Accessed: Sept. 27, 2016. doi: 10.1088/17489326/5/1/014010.

SIMUNEK, J. et al. The HYDRUS-1D Software package for simulating the movement of water, heat, and multiple solutes in variably saturated media. Version 4.16, HYDRUS Software Series 3, Department of Environmental Sciences, University of
California Riverside, Riverside, California, USA, 2013. 340 p. Available from: <http://igwmc.mines.edu/software/igwmcsoft/ HYDRUS1D-4.16.pdf>. Accessed: Sept. 27, 2016.

THORTHWAITE, C.W.; MATHER, J.R. The water balance. Publications in Climatology, v.3, p.1-104, 1955.

TIRONI, L. F. Simanihot: Um modelo de simulação da cultura de mandioca e sua aplicação em clima futuro no Rio Grande do Sul. 2016. 172p. Tese (Doutorado em Engenharia Agrícola) Universidade Federal de Santa Maria, 2016. 